\author{
Yuan Zhang*, Yuyang Ge \\ Shanghai International Studies University, China, Shanghai \\ *e-mail: zyirt@yahoo.com
}

\title{
RELIGIOUS NATIONALISM AND POWER VACUUM IN THE MIDDLE EAST
}

This article is regarded for religious beliefs that can be combined with nationalism to provide a mobilization source for national self-determination. With the declining of quasi-state "Islamic State", and there can be found a temporary power vacuum in the former controlled territory of Islamic State of Iraq and al-Sham (ISIS). Similar like in the post-colonial and post-cold war eras, when the withdrawal of external powers created a power vacuum, religious nationalism involved in the reconstruction of subsequent orders, and the new regime often embodied criticism and revision of the previous political system, political structure, and of course ruling culture. The cultural environment of Islam shapes indigenous nationalism. Religious beliefs can provide sources of aggregation and mobilization for self-determination. This paper argues that since the ISIS showed extremism characteristics of the close combination of violence and religion, those national independent forces, rooted in the local religious society, have to revalue their religious security.

Key words: religious nationalism, power vacuum, Islamism, Kurds, Middle East, self-determination.

\author{
Юань Ажаң", Юйяң Гы \\ Таяу Шығыс Институты, Шанхай халықаралық зерттеулер университеті, Қытай, Шанхай қ. \\ *e-mail: zyirt@yahoo.com
}

\section{Аіни ұлтшымдық және Таяу Шығыстағы бимік вакуумы}

Бұл мақала ұлттың өзін-өзі анықтауы, бірегейленуі үшін қажетті болып табылатын біріктірудің қайнаркөзін қамтамасыз ететін ұлтшылдықпен ұштасып жатқан Аіни нанымдарға арналған. «Ислам мемлекеті» квазимемлекетінің құлдырай бастауымен, сондай-ақ, бұрынғы Ирак пен Шам Ислам мемлекетінің (ААИШ) бақылауы, билігі астында болған аймақтарда уақытша қуат вакуумы болу ықтималдығы бар. Отарлаудан кейінгі және суық соғыстан кейінгі дәуірдегі сияқты, билік үстемдігі жүріп тұрған сыртқы державалардың кетуі салдарынан туындаған қуат, яғни билік вакуумы, аталмыш аймақта орын алған жағдайдан кейінгі жағдайды қалпына келтіруге қатысқан Аіни ұлтшылдық, сондай-ақ, орнаған жаңа билік режимі көбінесе бұрынғы саяси жүйені, яғни саяси құрылымды және әлбетте басқарушы мәдениетті сынау мен қайта қарауды қамтиды. Қалыптасқан исламдық мәдени орта жергілікті ортада ұлтшылдықты қалыптастырады. Аіни нанымдар өзін-өзі анықтау, бірегейлендіру жолында жинақтау және жұмылдыру көздерін ұсына алады. Бұл мақаяада ААИШ экстремизм сипатындағы зорлық-зомбылық пен діннің арасындағы үйлесімді сипатты көрсетіп бергендіктен де, жергілікті Аіни қоғаммен терең байланысты болып келетін ұлттық тәуелсіз күштер өздерінің Аіни қауіпсіздігін қайта бағалауы керек деп тұжырымАайды.

Түйін сөздер: діни ұлтшылдық, билік вакуумы, исламизм, күрдтер, Таяу Шығыс, өзін-өзі анықтау.

\section{Юань Ажанг*, Юйянг Гы}

Институт Ближнего Востока, Шанхайский университет международных исследований, Китай, г. Шанхай, *e-mail: zyirt@yahoo.com

\section{Религиозный национализм и вакуум власти на Ближнем Востоке}

В Аанной статье Аается всесторонний анализ проблемы относительно религиозного убеждения, которые могут быть объединены с национализмом и которые могут послужить основой Аля обеспечения и источником мобилизации Аля национального самоопределения. С упадком квазигосударства, так называемого «Исламского государства», может быть обнаружен временный вакуум власти на территории, ранее контролируемой Исламским государством Ирака и Аль-Шам (ИГИА). Подобно эпохам постколониальной и постхолодной войны, когАа уход внешних сил создал вакуум власти, как правило, религиозный национализм участвовал в восстановлении последующих порядков, а новый режим часто воплощал критику и пересмотр 
предылущей политической системы, политической структуры и, конечно же, господствующей культуры. Именно культурная среда ислама, во многих случаях, формирует местный национализм. Поэтому, как правило, религиозные убеждения могут служить основой и источником объединения и мобилизации Аля самоопределения. В данной статье, в результате всестороннего анализа современной политической и религиозной ситуации в ряде стран утверждается, что поскольку ИГИА продемонстрирова^ экстремистские основания тесного сочетания насилия и религии, независимые национальные силы, укорененные в местном религиозном обществе, Аолжны переоценить свою религиозную безопасность.

Кмючевые слова: религиозный национализм, вакуум власти, исламизм, курды, Ближний Восток, самоопределение.

\section{Introduction}

On April 30, 2018, the U.S.-led Joint Forces Command in Iraq announced its suspension of work, and its main forces would no longer maintain support and cooperative operations with the Iraqi government forces that symbolized the end of the major operation combating the "Daesh" organization. (ElGhobashy and Sonne, 2018) ISIS is an extremist organization, a terrorist organization and a quasi-state that combines religion and violence. ISIS ruled its territories in a tyrannical and coercive way. Beginning in 2017, under the siege of multinational forces, ISIS has gradually lost control of hundreds of thousands of square kilometers of territory, millions of people and also its political appeal and religious attraction. Since then, politics in the Middle East has entered the post-ISIS period. In a post-ISIS power vacuum area, many political forces vied to dominate and lead this region, among these political forces, the nationalist forces is one of the major competitors. To achieve these goals such as self-determination and establishing a new state and government, all the forces should meet the needs of resolving the division of power with the original sovereign states, redefine the national borders with their neighbors, and extensive worldwide recognition is important. On those lands that were once controlled by ISIS, religion is deeply rooted in the core of local national character, national culture, and national cognition, as religious nationalism is a political existence that cannot be ignored.

This article analyzes that after the demise of ISIS, the nationalist forces weakened the religious political behavior in the process of striving for national self-determination that aimed at to theoretically deducting disintegration of the original extremist ruling power.

\section{Scientific research methodology}

The study was conducted through theoretical, historical and comparative analysis. The methodological basis for explaining the impact of religion toward the political power on the philosophical socio-cultural phenomenon was fulfilled in the field of religion from a local and global point of view.

\section{Main part}

The nationalist forces deliberately diluted the religious effect of its nation to meet the expectations of the outside secular order in exchange for external support for national independence. However, if the externalized expression of religious belief is suppressed and once national self-determination and political development cannot meet the expectations of the people, the future political situation may not only turn to religious revival but also slide to the abyss of extremes.

1. The Position of Religious Nationalism in a Power Vacuum

After the decline of ISIS, a quasi-sovereign state, most non-Middle Eastern countries which far away from the war center were deeply worried about the accompanying threat of extremist repatriation, as the transnational movement for whom was recruited by the former ISIS would increase pressure on national security. As for the forces, remaining in the territory used to be controlled by ISIS, it is even more urgent to use the limited power vacuum to fight for their own dominance and leadership. At this time, the anxieties of all parties come from how to confirm the maintenance of the power vacuum formed by the withdrawal of ISIS, distinguish between political allies, stakeholders, identify available sources of aggregation, mobilize identification, and choose political tactics such as the reasons that can be publicly announced to legalize the seizure of power. Under the vacuum of power, religious nationalism is faced with the difficulties of how to prioritize national autonomy, maintain religious survival, and seek religious development.

1.1. Contention for Dominance in a Power Vacuum

The period of power vacuum will produce reflections on the political power and political 
system that predominated in the earlier period. New systems are often designed to adjust, unify and modify the previous system. It can be seen that after the current withdrawal of power from the area that ISIS controlled before, religious nationalism often lays an important mass psychological foundation for the subsequently happened independence movement. At its peak, ISIS changed Syria's political situation, destroyed the security mechanism on the border between Iraq and Syria, and caused large-scale exile of ethnic groups. The analysis of the above changes mostly draws on the hegemonic heritage traditionally, similar to narratives of legacy of "Sykes-Picot" conspiracy and returning to Islamic principle. (Hamdan, 2016: 606) Facing the regional power vacuum formed by the retreat of ISIS, local political forces quickly fell into a new competition for dominance.

In the power vacuum of the post-ISIS era, multinational forces such as nationalism, neighboring countries, regional powers, extraterritorial powers, and their military alliances vertically and horizontally compete or ally with each other for regional dominance. When it comes to the changes of making major decisions, the former ISIS life model is a reference for defending the extreme resurgence of local religions, and cracking down on the residual forces of ISIS is also a common reason for dispatching troops. For example, on January 14, 2018, the United States and its leading anti-terrorist alliance announced that it would form and deploy a "border security force" mainly composed of Kurdish forces at the border in northeast Syria. Although the United States claimed to deploy border security forces to combat the remaining ISIS forces, the Syrian government, Russia, Turkey, and Iran expressed their opposition quickly and clearly, accusing each other of fostering separatist forces and destroying the original borders arrangement.

Since the era of decolonization, the strategy of sending troops to participate in confrontational wars between the great powers to achieve independence has been on the main line of the separatist movement. It can be predicted that conflicts and wrestling of internal and external forces in order to compete for leadership and domination will repeatedly appear in the power vacuum after the defeat ISIS, but judging from the extraterritorial response to the independence referendum in Iraqi Kurdish area, neither the governments of neighboring countries and western countries would not support the Kurds to declare direct independence in the Kurdish region in the short term.

\subsection{Nationalism's Religious Sources}

Religious nationalism regards religion as the core tie for maintaining its own nation, and religious belief as an important source of gathering and mobilizing people. Religious nationalism combines the characteristics of national religion with nationalism and religion serves the realization of the national political interests in operation. Religious nationalism often plays a role in breaking away from powerful rule or establishing a new government after the war, such as the Tamil secession movement in India. There are multiple pan-ethnic thoughts in the Middle East, such as Pan-Arabism, Pan-Turkism, and Pan-Islamism. At the same time, various ethnic groups generally have certain resistance to external power. Middle Eastern scholars who criticize nationalism believe that it is precisely Christians who have influenced Arabs to accept nationalism, and that the development of nationalism in the Arab population has in turn contributed to the emergence of Israel (Naqavi, 1884: 38). Anti-Americanism studies in the U.S. believe that religion, which mainly refers to Islam, together with the special political structure of Arab countries, has caused the anti-American orientation and mistrust of the United States in the Middle East (Lynch, 2007: 196). Religion is a tradition in Middle Eastern society, and it has always been intertwined with the local countries' realization of national rejuvenation and resistance to external hegemonic intervention. Anti-power independence movements that use religion as the motivate of nationalism in various places have not only provided successful experiences of ethnic integration with religion, but also warned of the implicit contradiction between religious identity and allegiance to the nation-state.

First, nationalists can use religious traditions to awaken national awakening. In the post-colonial era, religious nationalism had played a positive role in promoting the independence of the colonial countries. In the post-cold war period, religious nationalism also played a role in helping small and weak nations to seek new national identity. As Philippines fight against the dictatorship of the Spanish church, seeking independence after the disintegration of the former Yugoslavia, religious nationalism were once important forces in the process of national self-determination. It also played an important role in the independence process of India and Palestine. For example, Bal Gangahar Tilak relied on the Bhagavad Gìtā (Veer, 1994: 70) to promote Hindu people's national confidence and national awakening to actively participate in the anti-British independence movement. 
Second, the overlap of religious elites and nationalist elites helps to resist power. In the 1920s, in the marginal desert areas of northern Algeria, many of the Mzabi reformers involved in anticolonial and nationalist movements in Algeria and Tunisia were also elites of the Reformation. They combined religious reform, Pan-Islamism movements, pan-Ibadi anticolonial movement, panMaghribi anticolonical movement, and Algerian nationalism to fight against colonialism (Ghazal, 2015: 59). Similarly, at the end of the 1970s, some Afghan guerrillas would endow the national resistance against the Soviet as "holy war" against the foreign atheists and the Orthodox Church.

Third, the contradiction between religious belief and national belief lies in the conflict between religious piety and national loyalty if the nation is founded on religious nationalism. Benedict Richard O'Gorman Anderson once made a comparison. If one changes "my country, right or wrong" to "my religion, right or wrong", it would easily understand the division between religion and nationalism, in believers' eyes, the religion they believe in cannot be wrong at all (Anderson, 1998: 360). However, the principle of national self-determination that has been widely accepted since the last century means that sovereignty belongs to the people, but not God, or the other gods (Fox, 2004: 26). Unless the Kingdom of God is established, religious nationalism will eventually encounter the contradiction of supreme power and glory. The complexity of religious nationalism can be seen here.

2. The Ambiguity of Religious Status in the Independent Movement

Religious nationalism is a mixture of both nationalism and religion, which means that religious nationalism has two main characteristics, ethnic and ideological. The difference is whether religion is the degree of ethnic identity or whether religion is used as a substitute for political ideology (Juergensmeyer, 1996: 2-4). Generally speaking, the principle of national self-determination leads to the equal pursuit of the right of national self-determination. According to the General Assembly resolution 1514 $(\mathrm{XV})$, as to complete decolonization, "all peoples have the right to self-determination; by virtue of this right, they can freely determine their political status and freely pursue economic, social and cultural development" (1). Due to the principle of national self-determination, dozens of countries gained independence after World War II. In the context of the nationalist independence movement, population and territory are things that national groups expect, but ideology is not a necessary.
Religious nationalism is ambiguous and unstable. The theoretical discussion of religious nationalism focuses on whether religion belongs to nationalism or nationalism is united in the spirit of the banner of religion. The debate is whether religious nationalism is the nationalism, which emphasizes nationalism, or it is the nationalism only highlights its characteristics of religion. For example, scholars of comparative politics who specialize in the study of ethnic groups in Southeast Asia believe that religious nationalism is closely related to the religious obligations of ethnic groups, which means comparing religion as the cultural system that constitutes the nation to analyze Southeast Asian ethnic groups (Geertz, 2017: 155). In the context of modern international politics, the theoretical debate on religious nationalism revolves around the influence of religious-driven nationalism and external political forces, nations and other religious groups' interactions on political trends, and discusses religious nationalism's conflicts and cooperation with interference forces, state-led political legitimacy, and other elements that unite the nation.

Competing with national self-determination, nationalism with more republican characteristics, according to its research, is superior to the xenophobic, narrow nationalism. Patriotism loves existing countries and is defensive in nature, while nationalism is more closely related to new power and greater prestige (Viroli, 1997:2). The contradiction is that if nationalists pursue national self-determination and establish an independent nation-state, the state often means homogeneity and standard residents, rather than emphasizing the single character of the dominant nation. It can be understood as the higher the degree of modernization, the more probability of anti-nationalism (Hobsbawm, 2012: 89-90). Advocating patriotism for national loyalty, promoting the worldwide religion could coexist with differences with the nationalism ideology that emphasizes uniqueness. The broadness standard of judging a nation has caused religious nationalism to face the competition of national concepts in the process of splitting and establishing an independent state from an existing sovereign state.

In the struggle for the establishment of an emerging nation-state, nationalists and their supporters will always believe that the newly established country will give everything to the new life: people as masters, rapid economic growth, social equality, cultural regeneration, national supremacy and the end of colonial or external rule (Geertz, 2017: 252). However, the nationalistic persuasion with high emotions is exclusive, and the independent 
movement only supported by national emotions is always inevitably anticlimactic as its ending is either mediocre or replaced by another extreme trend (Snyder, 2000: 58). If the emerging nationalist regime has belligerent thinking, and insufficient internal and external political and military binding power, it will easily lead to recurrence of conflicts. The emergence of religious extremism will be one of its alarming consequences.

3. Restrictions on the Expression of Religious Externalization in Turbulent Areas

With the demise of the "Caliphate state " of ISIS, what renewed is the desire to establish a new country and new rule, with the rise of nationalist political forces that want to split and independence, and also new turbulence and war to establish a new country, although they are cruel but still necessary. Religion is not the only reason for the founding of a nation by war but it is undoubtedly a "spiritual weapon" (Tang, 2013: 131) that can be used to wage war, praising heroes and dwarfing opponents.

No matter it is religious radical politics that starts with faith or extreme right-wing radical politics founded by ideology as a slogan, radicalism uses hatred as its motivating factor. Islamic militants, like early European extremists, are keen to build power through violence. Since the war in Afghanistan in 1980s, radical Islamic militants have revived the concept of Jihad as a collective obligation (Katzenstein and Keohane, 2007: 282). The expression of extremist religious externalization reveals the anxiety about the status of the nation behind the supporters' extremism, the hatred of other ethnic groups, and finally manifests itself in the elimination of opponents by using forces of violence without any hesitation. Islamic extremism can be combined with national separatism, and it is prominently manifested as misinterpretation and abuse of "Jihad". By interpreting "Jihad" as a force attack on heretics and aliens, it incites ethnic contradictions and encourages believers who do not know the truth to take extreme actions to condone national separatism and undermine peace and stability.

Mark Juergensmeyer, a researcher of religious nationalism, believes that ISIS is essentially a combination of the Sunni Arab intensive movement, the global jihad movement and the doomsday movement in a worldview (Juergensmeyer, 2018: 20 ). It should be noted that militarized and extremist religious nationalism has appeared in various religions, which does not mean that any religion can be completely independent. Militarizing Buddhists have appeared in Japan, Sri Lanka, Thailand, and
Myanmar (Jerryson, 2010: 4-9). From a historical perspective, religious nationalism centered on the theory of destiny has helped the United States to sanctify, legalize, and rationalize the expansion of overseas territories during the America's foreign wars. At that time, Americans considered expansion as the sum of military power combined with reforming culture, making profits, and saving souls, all of them could be explained as expansion.

From the data analysis text that counts Lebanese Muslims' views on ISIS, it can be seen that those who are more loyal to the Islamic creed are more likely to show their willingness to support ISIS. The religious and political goals of establishing the real "Caliphate State" by ISIS have resonated in the fundamentalist sense among the Lebanese Sunni Muslim community. Especially for those who are loyal to political Islam, their support for ISIS is much higher (Haddad, 2017: 257). In the territory and surrounding areas once controlled by ISIS, also the living soil of political Islam, there may hidden a large number of people who support fundamentalist doctrines.

Nationalism is mainly a political principle that advocates the co-location of political units and national units (Gellner, 2006: 1). At present, it seems that in the post-ISIS period, the separatist forces in the formerly controlled territory, or national independence forces, will basically achieve the goal of more regional ethnic autonomy than establishing an independent state. The goal of returning to ideology is to place the country after independence. Political autonomy is often a better medium-term goal for nationalism. In the struggle for national self-determination, nationalist and political units are symbiotic.

Moreover, as far as individual nationalists are concerned, the political platform for the establishment of an independent state may not be the center of all nationalist movements. In many cases, the elites of the nationalist movement only use the political goal of establishing a country as a bargaining chip with other political forces, gradually achieving the purpose of expanding the scope of autonomy and narrowing the area of state power control. Establishing an independent state at this time is a political means of gaining more common interests in the name of the nation.

At this stage of struggling for national independence peacefully, at least the Kurds in Iraq are reluctant to openly embrace Islam's integration into their own national identity as their typical externalized expression. For Kurdish nationalists in Iraq, sects divide democratic Iraq. Shiites vote for 
Shiite religious parties, and Sunnis support Sunni religious parties and former Arab Ba'athist parties. They declared that the Kurdish group believes that it would go against the Kurdish nation-state if only emphasizes on establishing an Islamic state, as "the Kurdish national identity will be hidden under the Islamic flag" (Al-Marashi, 2005: 156).

4. Predicament of Religious Nationalism

Compared with religion, the basis of national identity seems to be more objective, such as based on kinship, region, and language, but in essentially, religion and ethnicity are concepts that are composed of ambiguous and flexible historical myths without certainties. In view of the extremely notorious religious extremism of ISIS, in the post-ISIS period, all parties competing for political leadership should not only safeguard and expand the interests of themselves and allies, but also avoid the recurrence of religious extremist forces such as ISIS.

De-extremification measures are, on the one hand, autonomous internal measures and, on the other hand, external intervention measures. If only focusing on anti-extremism, it is easy for extra political participants in the world to reach a certain consensus. In terms of effect, de-extremeation efforts should help curb the spread and revival of regional extremism and help reduce incidents of religious terrorism in the short term, but may lose reasonable judgments on religious and cultural factors with the whole national identity and even affect the success of the founding of the country.

First, the Kurds consciously preached that their beliefs were moderate, and emphasized that they mainly adhered to Sufism. In fact, the moderates in the Islamic cultural circle, especially the Islamic forces that care deeply about the political and military support of the external non-Islamic world, will intentionally or unintentionally show their "harmless" character by approaching the alSufiyyah. Some religious figures involved in the Syrian Kurdish movement have defined al-Sufiyyah as Kurdish Islam (Tejel, 2009: 95.) For example, during the independence of Kosovo, Albanian Muslims also emphasized that their ethnic group mainly believed in al-Sufiyyah (Zhang, 2014: 216). The paradox here is that even al-Sufiyyah has historically been associated with armed and violent records (Schlee, 2008: 124). Before the Kurds in Turkey awakened to national consciousness, Islam was the source of their ethnic identity.

Second, Kurdish nationalists have formed a positive image of the Kurdish nation in the international community by participating in the fight against ISIS. By strengthening the image of the brave and unyielding resisters, they have gained widespread international sympathy; the road to independence seeks more and broader support. The campaign to strengthen the positive secularization of nationalism by promoting the heroic stories of women warriors was very successful. The story of the female soldier is a positive illustration of the success of the Kurds' publicity. In many media reports, a cool female soldier without a headscarf but holding a steel gun successfully attracted people's attention. To project to the outside world that this group of people fighting for the liberation of the nation is a signal of openness and bravery. However, it is necessary to pay attention to the particularity of female images, because the use of female images consistent with values in propaganda battles is an effective political strategy to attract attention and improve emotional appeal. Radical Islamic narratives have also praised young women and mothers for joining militant Islamist groups, claiming that they are challenging the unfair European and American political order by sacrificing their lives. In addition, these kinds of propaganda also catch lots of attention.

Third, removing the cross-ethnic religious identity that was once shared within the community to reshape the uniqueness of the nation, so that to promote external support from the side to increase the degree of regional ethnic autonomy. Compared with the surrounding Islamic countries, the secularization of Kurdish living quarters seems to go much further. According to Kurdish English media, the Iraqi Kurdish Autonomous Region and the Syrian Rojava Federation have required that all public schools under the administration must maintain religious neutrality and teach multiple religious courses since 2012 (Aqrawi-Whitcomb, 2015). So far, public education in the Middle East generally supports the only religion, Islam.

5. Religious Resistance to International Interference

America's international intervention strategy is often aimed at manipulating "regime change" and forcing rebuilding the state system in the target country. The interventionist behavior of the United States in cultivating agents and intensifying religious protests has been questioned in both directions of ethics and international legal procedures. Compared with European countries, the USA has been much less affected by the internal security risks caused by refugee flows in turbulent areas. After the rise of ISIS, US only adjusted the Syrian policy with the main goal of extremist organizations. America has been committed to helping Syrian opposition to overthrow the Bashar regime. The core of its 
intervention policy in the Middle East is to safeguard the regional interests and the scope of its power. It is envisaged that the replacement of the government and the reconstruction of the state system through intervention should all be secular.

Later in the Iraq war, US analysts believed that the USA government should urge the Kurds to postpone their political demands for complete independence because it was necessary to prevent other separatist forces in Iraq's post-war territory from following suit and worsening the peaceful situation of post-war reconstruction. To this end, the United States should not only provide extensive economic, security, and refugee assistance to the Kurds, but also to support the Kurds' ultimate independence when conditions permit (Byman and Pollack, 2006: BO1). The Iraqi reservoir area did receive a security dividend with the support of the West after the war in Iraq, and its economy developed rapidly. In general, after the Iraq war, the United States strengthened its military presence in Iraq, coupled with the weakness of Iraq's puppet government, but strengthened the fundamentalist power of the regional Islamic world, as it hates American military existing in the Middle East area.

According to Richard Ned Lebow's cultural theory of "honor overdesire", the Bush administration in the evangelical background originally expected that the U.S. military would be cheered as the welcomed liberators in Iraq after the war, just like military history expansion of endorsements of American religious nationalism used as Manifest Destin (Lebow, 2008: 439). However, in fact, the US forces after the Iraq war were considered as occupying forces. The supportive government lacked the support of the local people, and the local violent resistance caused violent revenge by the ruling party, which in turn formed the solidification of the occupant's image. Lebow believes that during the post-war reconstruction process, the United States provided people's livelihood guarantees for the Iraqi people, but it did not solve the subordinate depression of the Iraqi people in the post-war spiritual level.

The US invasion has exacerbated religious and ethnic tensions in Iraq, making it impossible to form an effective coalition government. This dilemma remained unresolved until the 2018 victory of the Iraqi elections by the religious nationalist Muqtada Al-Sadr and his alliance. Even after Iraq's victory over the ISIS, in fact, Iraq urgently needs to promote national reconstruction. However, due to the large number of domestic factions and serious religious divisions, coupled with the inability to form an effective election decision force after the failure of the Kurdish independence referendum, no faction can form a separate cabinet. After the election results were announced, the society fell into chaos.

Although the United States launched military intervention in the name of "responsibility to protect" in Libya, the United States also realized that one of the political costs of intervention was the rapid rise of Libyan Islamic political forces, and Islamic extremism also gained opportunities for proliferation and expansion. In order to avoid the recurrence of Islamic forces using the environment of foreign military intervention to enhance their influence, the US intervention in Syria did not apply the "responsibility to protect" concept. From the perspective of the traditional geopolitical analysis of American intervention, the US intervention in the Syrian civil war has strategic considerations to cut off the strategic alliance with Iran since the Bashar regime took office. America eases pressure on Israel's security environment by fighting against Hamas and Hizballah. US intervention is expected to include weakening anti-American religious alliances and ultimately establishing a secular political order in the Middle East.

Since globalization, the Islamic world has been facing the test of modernity and secularization. The international system prevailing in the era of globalization is mainly based on western modernity culture. Since the 1990s, an important change in Third World politics has been the failure of modernization (Haynes, 1994: 3). More specifically, the Third World has been dissatisfied with secular democratization solutions since the post-colonial era, especially in the post-Cold War era (Westerlund and Hallencreutz, 1996: 4). Dialectically, nationalism was originally a western concept for the Middle East. There is a mutual impact between Middle Eastern nationalism and Islam, as they development through the intersection. Religious nationalism is the product of contradictions. Religious renaissance was linked to the Third World's struggle for cultural liberation in order to reaffirm the native identity to fight against western cultural advantages. Hedley Bull called the cultural struggle based on indigenous religions a developing country's resistance to the West (Bull, 1984: 217).

Michael Walzer in the book The Paradox of Liberation: Secular Revolutions and Religious Counterrevolutions thought that the secular cause of national liberation has always faced two kinds of pressure: liberation from external oppression and liberation from the internal influence of external oppression. The tension between secular national 
liberation and religious revivalism belongs to the latter (Walzer, 2015: 1, 104). Nationalist elites must critically approach religious beliefs and customs in the process of self-adjustment to establish a country, because the latter is also another form of liberation, otherwise ignore those who value their past lifestyles, religious fanatics and religious extremism will soon be revived. Islamic radicalism has certain rebelism and is the legalization of political struggle using religious forms. However, unlike the political theology of struggle represented by Latin American liberation theology, radicalist resistance bears the notoriety of violence.

The internal structural constraints of nationalism's realization of the western secular political order come from the lack of governing power. A revised scholar of structural realism in international relations believes that if a regime rules a turbulent and divided regime, the external structure-system's influence may not be powerful for this regime because it does not mobilize the resources needed to formulate effective policies Ability (Schweller, 2006: 150-151). For example, the Kurds became the agents of the United States in the regional power, but when the civil war ended, the independence of the ruling government would be greatly restricted. On the one hand, the level of governance of the new government in power is insufficient, and it may not have sufficient policymaking capabilities to meet the requirements of the external system; on the other hand, the political system reconstructed under external intervention may not meet the real development requirements of the group. Because the issue of religious nationalism is not only a technical issue of institutional design, if the government fails to handle the relationship between the foundation of belief, national identity, institutional construction, and domestic governance, it will lead to the fundamental collapse of social development. Nation-state and Islamic standards are compatible, but in order to meet the external expectations of secular democracy, suppressing and covering Islamic values violates the law of religious development and may not prevent religious life from regulating or enlightening members the awareness of institution and regime by using a cultural way.

Western observers are tolerant of secularized nationalist liberation forces in the Middle East. In their eyes, pro-Western Syrian Kurdish political forces advocate "libertarian socialism" in the name of "Syrian Kurdistan" is far better than ISIS which is organized in the form of the medieval totalitarianism, superior to the secular nationalist tyranny of the Bashar's Ba'ath Party, and better than the Erdogan regime that is reviving Ottoman under "Putin-style rule (Totten, 2018). On July 12, 2018, the two-star flag was waved again in sight of the Omari Mosque. This ceremony was full of symbolic meaning, because Daraa was the first city to rebel against President Bashar Al-Assad in 2011. Protesters also held their first rally calling for government reforms in front of the Mario Mosque (Issa, 2018). The Syrian government's recapture of Daraa seems to mean that the civil strife that has been affected by the changes in the Middle East has gradually returned to the government's control from the beginning of the turbulence. Whether Syria's religious nationalism is reviving, active, extreme, or secular is still difficult to predict.

\section{Results and discussion}

Whether historically or psychologically, religion and nation are social communities where people are always full of strong emotions, voluntarily surrendering dignity and loyalty (Isaacs, 1997: 144, 171). In the past, the way the empire organized the nations of the country and prevented the disintegration of the empire was to provide "national-cultural autonomy". The national republic is integrated into the empire framework in the form of autonomous units or sovereign collective organizations, without being given a fixed place of residence. The absence of fixed land eliminates the possibility of political opposition between nations and nations. But the vacuum of power brought about by the demise of ISIS also brought land that was not under the control of authoritative forces, opening up the Pandora's Box for subsequent political forces to fight.

Although Les frontières $d u$ racisme talks about racism, the logical paradox of ethnic movements mentioned in the book deserves an analogy to similar nationalist movements. The book argues that although there are clear anti-racist regulations in international law around the world that require compliance with moral principles that prohibit any form of discrimination based on ethnicity and religion, the existence of anti-discrimination laws has strengthened the existence of races and ethnic groups and is equivalent to recognizing ethnic differences. Today's anti-racism has actually been reduced to: in order to reduce the number of democratic enemies, and after screening with alarmist arguments, we use safe racism to deal with unsafe racism (d'Appollonia, 2011: 95). The Kurds were regarded as a safe ethnic group when they jointly cracked down on ISIS, but this security positioning in the post-ISIS era was erratic. If extraterritorial forces want to use external 
forces to guide and promote the establishment of the secular order in the Middle East, and repeatedly emphasize the secular image of the Kurds, in fact, it not only acquiesces in the strong religious nature of the region, but also hurts the true inner expectations revive the feelings of believers in religious life. In other words, the establishment of advocacy and strengthening of secular order by external forces is likely to reversely strengthen the factual existence of religion in social groups. After getting rid of ISIS, it is emphasized that the anti-extremism and antiIslamic Kurdish national independence movement may face a comeback of extremism and militarized Islam in the future.

There are always concerns that religion will inevitably support radical politics, especially in the context of international Islamophobia. Of course, the factors that determine whether religious nationalist groups are militarized and the use of armed forces are multifaceted. For example, sectarian interests, emergencies, political ecology, external intervention, etc. may all play a role. However, it should be acknowledged that, from the perspective of conflicting Middle Eastern countries, religion provides "public space activities" to strengthen identity and information flow, which can promote positive attitudes towards war and exclusion (Hoffman and Nugent, 2015: 894).

When Turkey's Kemalism was building the country, left-wing forces proposed the establishment of socialist Turkey, and Kurdish activists proposed the right to national self-determination. To balance disputes among all parties, Islam was given the expectation of serving as the "core centripetal force" (Grigoriadis, 2012: 70) of the country. In fact, despite being a nation, the Kurds in Turkey, Iraq, Iran, and Syria have not formed a political movement that united to fight for Kurdish national rights, nor have they formed a truly unified political community based on Kurdish ethnic groups. Chinese scholars believe that, for today's Kurds, realistic expectations, or even ultimate expectations, are simply striving for national rights in the country where they live and equal national status. In any case, a qualified state needs to protect civilians and provide security, and if it fails to respond to other armed threats, including terrorism, it will also mean a state failure. The state is the form of political organization that is most conducive to promoting economic development, improving social security, and protecting people in the territory from external dangers under the current world structure (Lachmann, 2010: 130). For those ethnic minorities struggling in long-term turbulent and war-torn environments, longing for long-term peace, it will always be a political ideal for them to build a nation.

\section{Conclusion}

In the post-ISIS period, the extraterritorial and intraregional political forces' current security governance measures to curb religious extremist violence have had a certain effect. Local nationalist political forces have chosen to weaken religious external expression and participation. In the long run, overly suppressing the expression of beliefs implies the possibility of escalating religious security threats. If the successive policy makers regard conservative and radical voices as only a manifestation of minority diversity, and preserve them in the process of postwar reconstruction and shaping public policy under the framework of pluralism, then it can only be a serious hidden danger for the future political structure. National hatred and revenge on religious violence are far from over and post-war reconstruction in conflict areas will obviously be a long process. De-religious nationalism in order to de-polarize will likely have a profoundly negative impact on the regional security situation.

\section{References}

Ali Muhammad Naqavi. (1984) translated by Alaedin Pazargadi, Islam and Nationalism, Tehran: Islamic Propagation Organization, p. 38

Ali Nehme Hamdan, (2016) "Breaker of Barriers? Notes on the Geopolitics of the Islamic State in Iraq and Sham," Geopolitics, Feb. 29, p. 606 .

Amal Ghazal, (2015) "Tension of Nationalism: The Mzabi Student Missions in Tunis and the Politics of Anticolonialism," International Journal of Middle East Studies, Vol. 47, No. 1, p. 59.

Ariane Chedel d'Appollonia, Les frontières du racisme, Paris: Presses de Science Po, 2011, p. 95.

Benedict Anderson, (1998) The Spectre of Comparisons: Nationalism, Southeast Asia, and the World, New York: Verso, p. 360.

Clifford Geertz, (2017) The Interpretation of Cultures, New York: Basic Books, p. 155.

Daniel L. (2006) Byman and Kenneth Pollack, "What Next?" Washington Post, August 20, p. 801.

David Westerlund and Carl F. Hallencreutz eds. (1996) Questioning the Secular State: The Worldwide Resurgence of Religion in Politics, London: Hurts and Company, p. 4. 
E. Gellner, (2006) Nations and Nationalism, Oxford: Blackwell; Ithaca: Cornell University Press, p. 1.

Eric Hobsbawm, (2012) Nation and Nationalism Since 1780, Cambridge University Press, pp. 89-90.

Günther Schlee, (2008) How Enemies Are Made: Towards A Theory of Ethnic and Religious Conflict, New York: Berghahn Books, p.124.

Harold R. Isaacs, (1997) Idols of the Tribe Group Identity and Political Change, Cambridge: Harvard University Press, pp. 144, 171.

Hedley Bull, (1997) "The Revolt against the West," in Hedley Bull and Adam Watson eds., The Expansion of International Society, Oxford: Clarendon Press, 84, p. 217.

Ibrahim Al-Marashi, (2005 ) “Iraq's Constitutional Debate,” Middle East Review of International Affairs, Vol. 9, No. 3 , p. 156. Ioannis N. (2012) Grigoriadis, Instilling Religion in Greek and Turkish Nationalism: A “Sacred Synthesis”, Basingstoke: Palgrave Macmillan, p. 70.

Jack Snyder, (2000) From Voting to Violence, New York: Norton, p. 58.

Jeff Haynes, (1994) Religion in Third World Politics, Milton Keynes: Open University Press, p. 3.

Jonathan Fox, (2004) Bringing Religion into the International Relations, New York: Palgrave Macmillan, p. 26.

Jordi Tejel, (2009) Translated by Emily Welle and Jane Welle, Syria's Kurds: History, Politics and Society, London: Routledge, p. 95.

Marc Lynch, (2007) "Anti-Americanism in the Arab World," in Peter J. Katzenstein and Robert O. Keohane, eds., Anti-Americanism in the World Politics, Ithaca: Cornell University Press, p. 196.

Mark Juergensmeyer, (1996) "The Worldwide Rise of Religious Nationalism,” Journal of International Affairs, Vol. 50, Issue 1, Summer, pp. 2-4.

Mark Juergensmeyer, (2018) "Thinking Sociologically about Religion and Violence: The Case of ISIS," Sociology of Religion: A Quarterly Review, Vol. 79, No. 1, p. 20.

Maurizio Viroli, (1997) For Love of Country: An Essay on Patriotism and Nationalism, Oxford: Oxford University Press, p. 2.

Michael J. Totten, (2018) "No, The Syrian Kurds are not Terrorists," World Affairs, January 31, http://www.worldaffairsjournal. org/blog/michael-j-totten/no-syrian-kurds-are-not-terrorists.

Michael Jerryson, (2010) "Introduction", in Michael Jerryson and Mark Juergensmeyer, eds., Buddhist Warfare, New York: Oxford University Press, pp. 4-9.

Michael T. Hoffman and Elizabeth R. Nugent, (2015) "Communal Religious Practice and Support for Armed Parties: Evidence from Lebanon,” Journal of Conflict Resolution, Vol. 61, No. 4, p. 894.

Michael Walzer, (2015) The Paradox of Liberation: Secular Revolutions and Religious Counterrevolutions, New Haven: Yale University Press, pp. 1, 104.

Peri-Khan Aqrawi-Whitcomb, (2015) "Secularism: Essential to Kurdish Identity," Kurdistan24, November 22, http://www. kurdistan24.net/en/news/828209b9-b737-4253-88b2-af0e4e53dba1/Secularism--essential-to-Kurdish-identity.

Peter van der Veer, (1994) Religious Nationalism: Hindus and Muslims in India, Berkeley: University of California Press, p. 70. Philip Issa, (2018) "Syrian Government Raises its Flag over Cradle of 2011 Revolt," Associated Press News, July 12, https:// apnews.com/119b758e3e224491a9ecf7e3bf26692b.

Randall L. Schweller, (2006) Unanswered Threats: Political Constraints on the Balance of Power, Princeton, N.J.: Princeton University Press, pp. 150-151.

Richard Lachmann, (2010) States and Power, Cambridge: Polity, p. 130.

Richard Ned Lebow, (2008) A Cultural Theory of International Relations, Cambridge: Cambridge University Press, p. 439.

Robert O. Keohane and Peter J. Katzenstein, (2007) "The Political Consequences of Anti-Americanism," in Peter J. Katzenstein and Robert O. Keohane, eds., Anti-Americanism in the World Politics, Ithaca: Cornell University Press, p. 282.

Simon Haddad, (2017) “Accounting for Lebanese Muslims' Perspectives on the Islamic State (ISIS): Religious Militancy, Sectarianism and Personal Attribution," Defense \& Security Analysis, Vol. 33, No. 3, p. 257.

Siping Tang, (2013) The Social Evolution of International Politics, Oxford University Press, p. 131.

Tamer El-Ghobashy and Paul Sonne, (2018) "U.S. Disbands Command Overseeing American Ground Force in Iraq, As Major Combat Against ISIS Ends," The Washington Post, April 30.

Yuan Zhang, (2014) Religion's Functional Unit and Regional Conflict, Shanghai: Shanghai People's Publishing House, p. 216.

"Declaration on the Granting of Independence to Colonial Countries and Peoples (Adopted by General Assembly Resolution 1514 (XV) of 14 December 1960)," UN, http://www.un.org/en/decolonization/declaration.shtml. 